А.С. Пушкин в восприятии современных словацких русистов: подведение итогов

A.V. Zlochevskaya (Moscow, Russia)

\title{
Pushkin in Perception of Contemporary Slovak Researchers of Russian Literature: Summarizing
}

Интерес к А.С. Пушкину - к его жизни и творчеству - в словацкой русистике устойчив, имеет давнии традиции и значительные достижения ${ }^{1}$. Новая коллективная монография, созданная усилиями ведущих русистов современной Словакии с философского факультета университета им. Каменского в Братиславе «А.С. Пушкин в Словакии (1988-2015)»² продуктивно продолжает эту традицию, привнося новые изыскания, взгляды и подходы.

В современной словацкой русистике, как подчеркивает профессор А. Элиаш, в культуре и литературоведческой славистике назрела потребность «суммировать, упорядочить, систематизировть накопленные частные познания» (стр. 5). Ответом на этот запрос стал рецензируемый труд. Период с 1988 по 2015 г. авторы монографии считают переломным в истории рецепции А.С. Пушкина словацким культурным контекстом, так как именно в эти годы, во многом благодаря переменам идеологического и общественного климата, произошли качественные изменения в самом «образе» великого русского писателя на культурно-литературном пространстве Словакии.

Свое внимание словацкие русисты сосредоточили на базовом пласте рецепции - вопросах художественного перевода, как общих, так и более частных: переводы «Евгения Онегина» (глава профессора А. Элиаша) и повести «Метель» (глава профессора М. Кусы). Художественный перевод как самостоятельная литературная деятельность, подчеркивают словацкие ученые, выполняет целый комплекс важнейших культурологических функций: информативную, онтологическую, креативную, развивающую, дополняющую, социокультурную, эстетическую и др.

\footnotetext{
${ }^{1}$ Červeňák A. A.S. Puškin - človek a básnik. Nitra: Matica slovenská, 1989. 183 s.; Naš Puškin. Nitra: Filologická fakulta Univerzita Konštantína Filozófa, 1998. 223 s.; Puškinovské interpretačné variacie. Bratislava: Univerzita Komenského, 2000. 127 s.; Ruská literatủra v slovenskej kultủre v rokoch 1825-2015 / Ed. M. Kusá. Bratislava: Veda, 2015. 264 s.; Slovník slovenských prekladatel'ov umeleckej literatỏry. 20. storočie / Eds.: O. Kovačičová, M. Kusá. Bratialava: VEDA a ÚSvl. SAV, 2015. 464 s. и др.

${ }^{2}$ Eliáš A., Kusá M., Lukačová A., Šimková L. A.S. Puškin na Slovensku (1988-2015) / Ed. a ved. red.: A. Eliáš, M. Kusá. Bratislava: Univerzita Komenského, 2018. 190 s.
} 
Издательско-переводческая деятельность действительно является основой всех рецептивных процессов. В этом смысле сужение проблематики выглядит вполне оправданным: оно повышает конкретность изысканий, а тем самым способствует убедительности. Сокращение количественное повышает интенсивность. Однако вне сферы интереса словацких славистов оказались такие важные аспекты рецепции, как собственно анализ оригинальных пушкинских текстов, а также влияние творчества Пушкина на словацкую литературу. Сужение исследовательского диапазона следовало отразить в названии книги.

У истоков современной словацкой компаративистики стоят классические труды Д. Дюришина ${ }^{1}$, доказавшего, что доминантой рецептивных процессов всегда являются национальные особенности и потребности воспринимающего контекста. Основополагающий постулат концепции словацких славистов - признание того, что характер и особенности восприятия художественных ценностей инонациональным контекстом определяются его культурно-историческими потребностями в каждый исторический период.

Аналитическому рассказу о рефлексии личности и творчества нашего великого поэта посвящена глава «Функционирование переводов А.С. Пушкина в словацком культурном контексте». Свою главную задачу профессор М. Куса видит в том, чтобы проследить, как менялся сам «образ Пушкина» в читательском восприятии начиная со второй половины XIX в. и что привнес в контексте заявленной проблематики исследуемый период.

Автор подчеркивает антиисторичность утверждения о ведущей роли Пушкина в переводах из русской поэзии. Словацкие русисты Д. Дюришин, А. Попович, Э. Панова ${ }^{2}$ в своих классических работах убедительно показали «сложность положения Пушкина в переводах из русской литературы» (стр. 18).

Так, в XIX в., когда русская литература воспринималась по преимуществу в контексте идей панславизма и межлавянского единства, безусловным лидером читательского интереса, а соответственно, и печатной продукции была поэзия славянофила А. Хомякова, в то время как творчество Пушкина оказалось в тени.

В межвоенный период, после распада Австро-Венгрии и возникновения самостоятельного государства Чехословакия, художественный перевод обрел и еще одну очень важную функцию: он стал «неотъемлемой составляющей культуры эмансипированной нации и показателем уровня развития его культуры по отношению внешнему миру» (стр. 25). В эти годы пушкинское литературное наследие становится одним из средств национального самоопределения новой, чехо-словацкой межнацинальной общности.

В послевоенный, т.е. советский, период обращение к классическим, в том числе пушкинским, текстам было связано с потребностью вернуться к «проверенным ценностям», а в то же время с тем, что русская классика давала возможность критически анализировать и осмысливать общественное устройство - на примере царской России делать выводы относительно современного общества.

На фоне вполне понятного резкого спада в 1990-е гг. читательского, а соответственно, и издательского интереса к русской литературе наблюдалась парадоксальная «рецептивная ревитализация» интереса к русской поэзии со стороны

\footnotetext{
${ }^{1}$ Ďurišin D. Problémy literárnej komparatistiky. Bratislava: SAV, 1967. 198 s. и др.

${ }^{2}$ Popovič A. Ruská literatỏra na Slovensku v rokoch 1836-1875. Bratislava: Vydavatel'stvo SAV, 1961. 153 s.; Ďurišin D. Slovenská realistická poviedka a N.V. Gogol'. Bratialava: ÚSvl. SAV, 1966. 241 s.; Panovová E. Puškin v slovenskej poézii do r. 1918. Bratislava: Vydavatel'stvo SAV, 1966. 257 s.; Panovová E.Ruská a sovietská poézia na Slovensku (1918-1938). Bratislava: Veda, 1983. 121 s. и др.
} 
ученых русистов - к Пушкину прежде всего в связи с празднованием 200-летия со дня рождения поэта. В исследуемый период вышли в свет 295 научных публикаций по пушкинской теме: монографии, сборники статей, отдельные исследования и др., - а также концептуальные работы, посвященные собственно проблемам перевода и содержащие критику переводов художественных текстов Пушкина Я. Замбора, А. Валцеровой ${ }^{1}$ и др.

Значительными событиями в словацкой пушкиниане явились четыре перевода на словацкий язык полного текста одного из вершинных произведений русской художественной словесности - «Евгения Онегина»: С. Родицкого - в 1900 г., Я. Есенского - в 1942 г., И. Купца - в 1973 г. и Я. Штрассера - в 2002 г. (глава А. Элиаша «Четыре словацких перевода “Евгения Онегина"»). Каждый из переводов стал знаковым событием в истории рецепции Пушкина в Словакии, отразив не только потребности воспринимающего контекста и отвечая на его запрос, но и уровень переводческой культуры своего времени, а также различные этапы постижения творческой личности нашего национального гения.

Главное достоинство проведенного глубокого и вдумчивого и сравнительно-сопоставительного анализа - его концептуальность. А. Элиаш не ограничивается размышлениями над отдельными промахами, даже ошибками или, напротив, блестящими находками переводчика, но четко формулирует те основополагающие характеристики пушкинского текста, которые структурируют его внутреннюю и внешнюю формы, а потому должны найти свое адекватное решение в стратегии перевода.

Такими важнейшими константами пушкинского текста автор считает:

- ироничность как доминантную характеристику авторского нарратива;

- ироническое «остранение» Автора от повествовательного пласта;

- специфику образа Автора: он герой и повествователь одновременно;

- «стереоскопичность», много- и разноплановость изображения мира: переплетение и взаимодействие различных точек зрения, сюжетных линий, повествовательных пластов, литературных жанров, школ и стилей;

- уникальную стихотворную систему: ритмика, рифмовка, строфика.

В основе перевода всегда лежит динамическое взаимодействие категорий актуализации - архаизации. Это относится и к проанализированным словацкими ученым переводам «Евгения Онегина». Оптимальное сочетание обоих векторов приближение к современному читателю и близость к стилю и смыслу оригинала А. Элиаш находит в версии Я. Штрассера.

Главы, посвященные проблемам перевода, дополняют содержательный рассказ ведущего научного сотрудника «Словацкой национальной библиотеки» А. Лукачовой о музее А.С. Пушкина в Бродзянах (глава «Словацкий музей А.С. Пушкина в Бродзянах»), а также составленная Л. Шимковой весьма презентативная персональная библиография (всего около 400 позиций) «А.С. Пушкин в словацкой печати. Выборочная библиография (1988-2015)», которая является продолжением библиографии А. Матёвчика «Александр Сергеевич Пушкин в словацкой печати (1826-1987)» (1998) и составлена по материалам «Словацкая национальная библиотека» (с дополнением материалами из периодики).

Несмотря на радикальное изменение общественно-политической ситуации в стране, Пушкин, пишет А. Элиаш, остается «живым и продуктивным импульсом как для словацкого читательского и переводческого сообщества, так и для

${ }^{1}$ Zambor J. Preklad ako umenie. Bratislava: Univerzita Komenského, 2000. 239 s.; Valcerová A. Hl'adanie súvislostí v básnickom preklade. Prešov: Prešovská univerzita, 2006. 220 s. 
словацкого литературоведения и истории» (стр. 15). Современным словацким читателем, развивает эту мысль М. Куса, пушкинские художественные тексты воспринимаются не как архаичная «классика», но как нечто новаторское, а порой и шокирующее (стр. 32).

Рецензируемый труд словацких ученых позволяет увидеть, что литературное наследие А.С. Пушкина, «несмотря на бесспорный и давно признанный статус литературной классики, в своем словацком варианте не перестает будоражить наше культурное сообщество сознанием чего-то недоговоренного или по крайней мере не вполне выраженного» (стр. 34). Эти слова А. Элиаша о «Евгении Онегине» вполне оправданно можно отнести и к рецепции всей русской литературы. Ощущение неполноты постижения оказывается весьма продуктивным, ибо стимулирует дальнейшее движение и развитие современной русистики в Словакии.

Сведения об авторе:

Алла Владимировна Злочевская,

доктор филол. наук

ст. научный сотрудник

филологический факультет

МГУ имени М.В. Ломоносова
Alla V. Zlochevskaya,

Doctor of Philology

Senior Researcher

Philological Faculty

Lomonosov Moscow State University

zlocevskaya@mail.ru 